\title{
EFFECT OF POTASSIUM SALTS ON ONION PURPLE BLOTCH INCIDENCE AND SOME PHYSIOLOGICAL AND YIELD PARAMETERS IN ONION SEED PLANTS
}

\author{
Hanan S. Sof ${ }^{1}$, Hoda M.H. ahmed ${ }^{1}$, Maisa L. Abd-El-Moneim ${ }^{2}$ and Mohamed
} Hassan $^{1}$

${ }^{1}$ Dept. of Agricultural Botany (Plant Pathology), Fac. of Agric., Fayoum Univ., Egypt.

${ }^{2}$ Central Lab. of Organic Agriculture, ARC, Giza, Egypt.

Corresponding author: Hoda Ahmed hmh03@fayoum.edu.eg

\section{ABSTRACT}

Purple blotch disease is one of the most destructive diseases of onion in Egypt, which could cause $100 \%$ loss of onion seed production. The excessive use of chemical fungicide harms the environment and natural balance, leading to find another safe and effective alternative controlling onion purple blotch disease. Field experiments were conducted at Demo in El-Sultan Bahnas village, Fayoum County at El-Fayoum Governorate during the growing seasons 2017/2018 and 2018/2019 on onion for seed production. Plants were sprayed with four potassium salts; potassium silicate (K-silicate), potassium citrate (K-citrate), dipotassium phosphate $\left(\mathrm{K}_{2} \mathrm{HPO}_{4}\right)$ and potassium carbonate $\left(\mathrm{K}_{2} \mathrm{CO}_{3}\right)$. Two control treatments one with distilled water and the other with mancozeb $80 \% \cdot \mathrm{K}_{2} \mathrm{HPO}_{4}$ gave the best result in decreasing disease incidence or disease severity in leaves and flower stalks in respectively, followed by $\mathrm{K}_{2} \mathrm{CO}_{3}$ and $\mathrm{K}$-silicate. While, the treatment of $\mathrm{K}_{2} \mathrm{CO}_{3}$ gave the highest inflorescences' fresh and dry weights followed by $\mathrm{K}_{2} \mathrm{HPO}_{4}$, then K-Citrate. The treatment of $\mathrm{K}_{2} \mathrm{HPO}_{4}$ generated the highest inflorescence and yield components compared to control treatment. K-silicate application exceeded the all other treatments and led to significant increases in free phenols and reduced sugars contents in onion leaves compared to control treatment. Examined Potassium salts in this study gave promised safe alternative control methods for onion purple blotch in onion seed production with reference to the chemical fungicide.

KEYWORDS: Onion seed, potassium, silicate, citrate, phosphate, carbonate, purple blotch

\section{INTRODUCTION}

Onion represents one of the most important and economic crops in Egypt. The economic importance of this crop appears in both local consumption and exportation purposes. Onion cultivated area was 189000 feddans and yielded 2863000 tons in 2017 (CAPMAS 2020).

Purple blotch disease is one of the most destructive diseases of Allium species in Egypt. The disease is more severe for seed crops if comparison to bulb crops, sometimes causing 100\% loss of onion seed production (Quadri et al., 1982, Gupta and Pathak, 1988 and Abdel-Rahim et al., 2016). The wide spread use of fungicides to control plant diseases led to an increase of health hazards due to their toxic residual and pollution effects. Therefore, using some other means of disease control instead of agrochemical is strongly encourage. Using safe mineral salts to control plant pathogenic fungi have received considerable attention as an alternative strategy (El Rafai et al. 2003)

Potassium is a major plant nutrient, which is essential for a variety of physiological processes i.e., photosynthesis, enzyme activation and contribution to

Fayoum J. Agric. Res. \& Dev., Vol. 34, No.2 July, 2020 
maintenance of water status in plant tissues (Marschner, 2012). Certain researches were conducted explaining the effect of some potassium salts on disease control. As the mechanisms proposed by Perrenoud (1990) explaining dipotassium phosphate with its disease-suppressing effect by its direct effects; on pathogen multiplication, development and survival, and plant metabolism and, consequently, pathogen food supply. Moreover its influence on plant defense responses and stomata function, which affect the establishment and spread of the pathogen inside the plant phosphates manifest antifungal activity by induction of systemic acquired resistance (SAR).

While, the inhibitory effect of bicarbonate on fungi was explained by Palmer $\boldsymbol{e t}$ al., (1997) by reducing the fungal cell turgor pressure which resulted in collapse and shrinkage of hyphae and spores, and consequent inability of fungi to sporulation. This could be considered as alternative safe control with very low mammalian and environmental toxicity profile (Jamar et al., 2007; Youssef et al., 2012 and Anonymous (2016)

Where, silicon plays role in growth improvement, photosynthesis increment, efficiency of transpiration and evaporation, increasing the strength of leaves and chlorophyll concentration per leaf area and product quality (Hwang et al., 2005 and Khalifa $\boldsymbol{e t}$ al., 2017), in addition to the state of potassium silicate as one of the silicon fertilizers which contain $27 \%$ of silicon oxide (Reezi et al., 2009).

Potassium citrate is potassium salt of citric acid which considered one of the most important organic acids in the respiratory pathways into plant cell. Additionally, citric acid plays an important role in plant metabolism, as nonenzymatic antioxidant, in chelating free radicals and protecting plant from injury could result in prolonging the shelf life of plant cells and improving growth characters (El-Beltagi et al., 2017).

Certain researches reported the efficacy of mancozeb as an active ingredient of fungicide controlling the purple blotch in onion (Bhosale et al., 2009 and Behera et al., 2014).

The aim of this study was to evaluate the effect of certain potassium salts (citrate, silicate, phosphate and carbonate) on; a) the disease incidence of purple blotch on onion which was naturally infected; b) the growth and yield onion seed parameters, and c) some physiological characteristics.

\section{MATERIAL AND METHODS}

\section{Experimental design and description}

Field experiments were carried out in a Farm located at Demo in El-Sultan Bahnas village, Fayoum County at El-Fayoum Governorate. Soil in this farm belongs to light clay soil type, with $\mathrm{pH}$ value 7.6. Irrigation water comes from Nile River. Field experiments were carried out during two successive seasons 2017/2018 and 2018/2019 on onion (Giza-red)) for seed production.

Experiments were designed in a complete randomized blocks design (CRBD) with three replicates per treatment. Four different treatments of potassium salts were sprayed; potassium silicate $(\mathrm{KSI})$, potassium citrate $\left(\mathrm{C}_{6} \mathrm{H}_{5} \mathrm{~K}_{3} \mathrm{O}_{7} \cdot \mathrm{H}_{2} \mathrm{O}\right)$, dipotassium hydrogen phosphate $\left(\mathrm{K}_{2} \mathrm{HPO}_{4}\right)$ and potassium carbonate $\left(\mathrm{K}_{2} \mathrm{CO}_{3}\right)$, other

Fayoum J. Agric. Res. \& Dev., Vol. 34, No.2 July, 2020 
EFFECT OF POTASSIUM SALTS ON ONION PURPLE

two control treatments negative (distilled water) and fungicide treatment (mancozeb $80 \%$ WP).

Onion bulbs used for these experiments were bought from field crop Institute, ARC, Giza, Egypt. These bulbs were cultivated in the eastern side of 70 $\mathrm{cm}$ width rows with $40 \mathrm{~cm}$ intervals. Each replicate was $33.6 \mathrm{~m} 2$ with three rows. Total numbers of plants / replicate were 120 plants. Single interval rows were left between treatments and replicates.

All plants received the same fertilizers and irrigation regime. Onion plants were treated with different treatment after 45 days of cultivation with exception to the fungicide treatment $(0.3 \%)$ which was applied after the disease dispersal as treated check. The treatments were sprayed seven times during the seasons with fifteen days intervals. Concentrated solutions of potassium salts were prepared at a concentration of $15 \%(\mathrm{v} / \mathrm{v})$, according to percentage of potassium in each compound.

\section{Disease assessment:}

Disease incidence of the treated onion plants was assessed during the growing seasons 2017/2018 and 2018/2019 on all the onion plants' leaves and flower stalks of each treatment ( 120 plant/replicate), whereas the disease severity was assessed on randomly 10 plants/treatment replicate. Disease assessments were conducted twice for leaves and flower stalks each season in the open field experiments (March on leaves and during May on flower stalks).

Disease incidence percentage was calculated according to the following formula (Ravichandran et al., 2017):

$$
\% \text { Disease incidence }=\frac{\text { Number of diseased plants }}{\text { Total No. of plants }} \times 100
$$

Disease severity was evaluated using 0-5 scale developed by Sharma (1986) and modified by the author where; 0:no disease symptom, 1: a few spots towards tip covering 10 per cent leaf area or flower stalks, 2: several purplish brown patches covering up to 20 per cent of leaf area.3: several patches with paler outer zone covering up to 40 per cent leaf area or flower stalks. 4: leaf streaks covering up to 75 per cent leaf area or breaking of leaves from center or flower stalks, and 5: complete drying of the leaves or flower stalks from center.

Whereas, the percent disease severity index (DSI, \%) was calculated using following formula given by Wheeler (1969):

$$
\text { DSI } \%=\frac{\text { Sum of all individual disease rating }}{\text { Total No. of plant assessed } \times \text { Maximum rating }} \times 100
$$

Morphological and yield characteristics

Samples of plants received different treatments were collected 90 days post planting. Some agronomical characteristics in treated plants, i.e fresh weight, dry weight, thousand-seed weight, seeds weight/10 plants, inflorescences No., inflorescences height, and inflorescences No./10 plants) were determined in late June. The expected seed yield was estimated for feddan for each treatment.

Fayoum J. Agric. Res. \& Dev., Vol. 34, No.2 July, 2020 
To deduce mode of action of different chemical salts treatments on disease control, samples of healthy plants were collected in randomize way and send to the lab for further analysis. Collected samples were used to determine free, conjugate and total phenols. Reduced and non-reduced sugars were also determined

Statistical analysis

All experiments were performed twice following Randomized Complete Block Design (RCBD). Analyses of variance were carried out using the MSTAT-C, 1991 program version 2.10. Fisher LSD test was employed to test for significant differences between treatments at $p=0.05$ (Gomez and Gomez, 1984).

\section{RESULT AND DISCUSSION}

\section{1- Efficacy of potassium salts in controlling onion purple blotch disease under field conditions}

Data obtained in Table (1) indicated that spraying of different mineral salts; $\mathrm{K}_{2} \mathrm{HPO}_{4}, \mathrm{~K}_{2} \mathrm{CO}_{3}$, K-Citrate and $\mathrm{K}$ - Silicate led to different degrees of protection against purple blotch disease. Data also showed that all treatments significantly reduced the percentage of disease incidence or disease severity in leaves and flower stalks and increased seed yield compared with control treatment. $\mathrm{K}_{2} \mathrm{HPO}_{4}$ gave the best result in decreasing disease incidence or disease severity in leaves and flower stalks $\left(29.41,26.53 \%\right.$ and $11.46,22.8 \%$, respectively). $\mathrm{K}_{2} \mathrm{CO}_{3}$ and $\mathrm{K}$ - Silicate occupied the second rank, decreasing disease incidence or disease severity in leaves and flower stalks. K-citrate occupied the least rank, decreasing disease incidence or disease severity in leaves and flower stalks (43.6, 32.07\% and 18.13, 40.16\%, respectively). $\mathrm{K}_{2} \mathrm{HPO}_{4}$ recorded the highest yield if compared with any other treatment, giving $303 \mathrm{Kg}$ seed yield/fed. K-citrate recorded the lowest quantity of seed yield compared with other treatments and gave $233 \mathrm{Kg}$ seed yield/fed, whereas controls gave $58 \mathrm{Kg}$ seed yield/fed. The obtained results are in good accordance with previous investigators such as Singh et al. (2004); Abd El-Aal et al. (2005), El-Bassiouny (2006) and Shafeek et al. (2013). These results may be due to the role of potassium element in metabolism and many processes needed to sustain and promote plant vegetative growth and development. Moreover, $\mathrm{K}$ plays a major role in many physiological and biochemical processes such as cell division and elongation and metabolism of carbohydrates and protein compounds (Marschner, 1995). The obtained results are in a good accordance with those recorded by Abd El-Aal et al. (2005), Abou El-Nasr and Ibrahim (2011), Saud et al. (2013) and Shafeek et al. (2013) who found that increasing potassium fertilizer levels increased plant height, number of leaves per plant and leaves fresh weight. Copper sulphate has antifungal effect on conidia and linear growth could be attributed to copper ions which can catalyze the production of highly hydroxyl radicals, with subsequent damage to lipids, proteins, DNA and other bioprocesses.

Potassium phosphate is used as a fertilizer and the principal source of phosphorus for plants in agriculture, but in some cases, when used as a foliar spray, disease resistance of plants is improved. In these regards, many investigations reported the use of potassium salts as a chemical agent for induction of plant resistance (Stromberg and Brishammar, 1991 and Yurina et al., 1993).

Fayoum J. Agric. Res. \& Dev., Vol. 34, No.2 July, 2020 
EFFECT OF POTASSIUM SALTS ON ONION PURPLE .162

Table 1: Effect of using different potassium salts in controlling onion (Giza-red) purple blotch under field conditions as average of the two seasons 2017/2018 and 2018/2019

\begin{tabular}{|c|c|c|c|c|c|}
\hline \multirow{2}{*}{ Treatment } & \multicolumn{2}{|c|}{ Disease Incidence on } & \multicolumn{2}{c|}{ Disease severity on } & \multirow{2}{*}{$\begin{array}{c}\text { Seed yield } \\
\text { (Kg/fedd) }\end{array}$} \\
\cline { 2 - 6 } & leaves & Flower talks & leaves & Flower stalks & $303.00 \mathrm{ab}$ \\
\hline $\mathbf{K}_{\mathbf{2}} \mathbf{H P O}_{\mathbf{4}}$ & $29.41 \mathrm{~d}$ & $26.53 \mathrm{~d}$ & $11.46 \mathrm{~d}$ & $22.8 \mathrm{ef}$ & $273.00 \mathrm{c}$ \\
\hline $\mathbf{K}_{\mathbf{2}} \mathbf{C O}_{\mathbf{3}}$ & $34.33 \mathrm{c}$ & $32.57 \mathrm{c}$ & $13.70 \mathrm{~cd}$ & $25.87 \mathrm{de}$ & $233.00 \mathrm{e}$ \\
\hline K-Citrate & $43.6 \mathrm{~b}$ & $32.07 \mathrm{c}$ & $18.13 \mathrm{~b}$ & $40.16 \mathrm{c}$ & $253.00 \mathrm{~d}$ \\
\hline K-Silicate & $32.26 \mathrm{c}$ & $38.00 \mathrm{~b}$ & $15.40 \mathrm{c}$ & $45.00 \mathrm{~b}$ & $228.00 \mathrm{f}$ \\
\hline Mancozeb & $25.38 \mathrm{e}$ & $21.5 \mathrm{e}$ & $18.8 \mathrm{~b}$ & $26.9 \mathrm{~d}$ & $28.00 \mathrm{~g}$ \\
\hline Control & $70.40 \mathrm{a}$ & $84.70 \mathrm{a}$ & $86.41 \mathrm{a}$ & $79.24 \mathrm{a}$ & 58.00 \\
\hline
\end{tabular}

Values with the same letter in the same column are not significantly different at $P<0.05$.

2- Effect of spraying different potassium salts on agronomical characteristics of onion plants

Effects of spraying application of different chemical salts on agronomical characteristics of onion plant are shown in Table (2). Data showed that all treatments led to significant increases in all parameters, which were measured, including fresh and dry weight of inflorescences /10plants, 1000-seed weight, seeds weight/10 plants, inflorescences No./ 10 plant, flower stalk height, and flower stalks No./10 plants) compared to control treatment. The treatment of $\mathrm{K}_{2} \mathrm{CO}_{3}$ gave the highest fresh and dry weights (880 and $454 \mathrm{~g}$, respectively) followed by $\mathrm{K}_{2} \mathrm{HPO}_{4}$, then $\mathrm{K}$ Citrate, while the control treatment gave the lowest fresh and dry weights, respectively. In addition, the treatment of $\mathrm{K}_{2} \mathrm{HPO}_{4}$ generated the highest inflorescence and yield components compared to control treatment. For potassium $(\mathrm{K})$, it activates numerous enzymes, which are critical for various metabolic processes, such as biosynthesis, transport, and transformation of sugars and starch (Lester et al., 2010 and Niu et al., 2013).

Potassium plays important roles in different processes in plants including photosynthesis, respiration, ion uptake and transport, protein synthesis and enzyme activation (Mengel, 2007). These results are in agreement with previous reports by Saud et al. (2013) and Shafeek, et al. (2013) who reported that increasing potassium fertilizer levels increased plant height, number of leaves per plant and leaves fresh weight.

Table 2: Effect of spraying different chemical salts on agronomical characteristic of onion plant under field conditions as average of the two seasons 2017/2018 and 2018/2019

\begin{tabular}{|c|c|c|c|c|c|c|c|}
\hline \multirow{2}{*}{ 芯 } & $\begin{array}{c}\text { Fresh } \\
\text { weight }(g)\end{array}$ & $\begin{array}{c}\text { Dry } \\
\text { weight }(g)\end{array}$ & \multirow{2}{*}{$\mid \begin{array}{c}1000 \text { seed } \\
\text { weight } \\
(\mathrm{g})\end{array}$} & \multirow{2}{*}{$\begin{array}{c}\text { Seeds } \\
\text { weight/ } \\
10 \text { plants } \\
\text { (g) }\end{array}$} & \multirow{2}{*}{$\begin{array}{c}\text { N. } \\
\text { flower } \\
\text { stalk } \\
\text { /plant }\end{array}$} & \multirow{2}{*}{$\begin{array}{c}\text { Flower stalk } \\
\text { height } \\
(\mathbf{c m})\end{array}$} & \multirow{2}{*}{$\begin{array}{c}\mathrm{N} . \\
\text { inflorescence } \\
\text { /10 plants }\end{array}$} \\
\hline & \multicolumn{2}{|c|}{$\begin{array}{c}\text { For Inflorescences } \\
/ 10 \text { plants }\end{array}$} & & & & & \\
\hline $\mathrm{K}_{2} \mathrm{HPO}_{4}$ & $816 b$ & $456 \mathrm{a}$ & $4.61 \mathrm{ab}$ & $172 \mathrm{a}$ & $5.33 \mathrm{a}$ & $85.2 \mathrm{a}$ & $54.66 \mathrm{a}$ \\
\hline $\mathrm{K}_{2} \mathrm{CO}_{3}$ & $880 a$ & $454 \mathrm{a}$ & $4.48 \mathrm{~b}$ & $155 \mathrm{~b}$ & $4.33 \mathrm{ab}$ & $79.43 \mathrm{~b}$ & $45.33 \mathrm{c}$ \\
\hline K-Citrate & $640 \mathrm{c}$ & $312 \mathrm{c}$ & $4.50 \mathrm{~b}$ & $132 \mathrm{~d}$ & $5.33 \mathrm{a}$ & $67.76 \mathrm{~d}$ & $47.66 \mathrm{bc}$ \\
\hline K-Silicate & $615 \mathrm{~d}$ & $334 \mathrm{~b}$ & $4.23 \mathrm{~b}$ & $143 \mathrm{c}$ & $4.33 \mathrm{ab}$ & $78.00 \mathrm{~b}$ & $42.00 \mathrm{~d}$ \\
\hline Mancozeb & $547 \mathrm{e}$ & $316 \mathrm{c}$ & $4.20 \mathrm{~b}$ & $135 \mathrm{~d}$ & $4.00 \mathrm{c}$ & $73.50 \mathrm{c}$ & $41.33 \mathrm{~d}$ \\
\hline Control & $179 \mathrm{f}$ & $77 \mathrm{~d}$ & $3.0 \mathrm{c}$ & $33 \mathrm{e}$ & $2.33 \mathrm{~d}$ & $48.63 \mathrm{e}$ & $28.66 \mathrm{e}$ \\
\hline
\end{tabular}

Values with the same letter in the same column are not significantly different at $P<0.05$.

Fayoum J. Agric. Res. \& Dev., Vol. 34, No.2 July, 2020 
3- Physiological changes (total phenols content and sugars formation) in the onion leaves and flower stalks that naturally infected by purple blotch disease and treated with different potassium salts chemicals.

Effects of spraying application of different chemical salts on the contents of phenolic compounds and sugars in leaves and flowering stalks of onion plant are shown in Tables (3 and 4). Data showed that K-silicate application exceeded the all other treatments and led to significant increases in free phenols and reduced sugars contents in onion leaves compared to control treatment. The treatment of K-Citrate occupied the second order for free phenols content, and $\mathrm{K}_{2} \mathrm{HPO}_{4}$ occupied the second order for reduced sugars content in onion leaves. Whereas $\mathrm{K}_{2} \mathrm{CO}_{3}$ and $\mathrm{K}_{2} \mathrm{HPO}_{4}$ Occupied the third order for free phenols content, and $\mathrm{K}_{2} \mathrm{HPO}_{4}$ and $\mathrm{K}_{2} \mathrm{CO}_{3}$ occupied the third order for reduced sugars content.

Table 3: Evaluation of the spraying of different chemical salts on total phenols content and sugars formation in onion leaves in open field as average of the two seasons $2017 / 2018$ and $2018 / 2019$

\begin{tabular}{|c|c|c|c|c|c|c|}
\hline \multirow{2}{*}{ Treatment } & \multicolumn{3}{|c|}{$\begin{array}{c}\text { Phenols } \\
\text { (mg/g fresh weight) }\end{array}$} & \multicolumn{3}{c|}{$\begin{array}{c}\text { Sugars } \\
\text { (\%) }\end{array}$} \\
\cline { 2 - 7 } & Free & Conj. & Total & Reduced & $\begin{array}{c}\text { Non } \\
\text { Reduced }\end{array}$ & Total \\
\hline $\mathbf{K}_{\mathbf{2}} \mathbf{H P O}_{\mathbf{4}}$ & $0.90 \mathrm{c}$ & $1.01 \mathrm{c}$ & $1.91 \mathrm{a}$ & $1.63 \mathrm{ab}$ & $1.19 \mathrm{bc}$ & $2.82 \mathrm{a}$ \\
\hline $\mathbf{K}_{\mathbf{2}} \mathbf{C O}_{\mathbf{3}}$ & $0.91 \mathrm{bc}$ & $0.98 \mathrm{c}$ & $1.89 \mathrm{a}$ & $1.52 \mathrm{bc}$ & $1.24 \mathrm{bc}$ & $2.76 \mathrm{a}$ \\
\hline K-Citrate & $0.97 \mathrm{abc}$ & $0.94 \mathrm{c}$ & $1.91 \mathrm{a}$ & $1.48 \mathrm{c}$ & $1.32 \mathrm{~b}$ & $2.80 \mathrm{a}$ \\
\hline K-Silicate & $1.01 \mathrm{a}$ & $0.90 \mathrm{c}$ & $1.91 \mathrm{a}$ & $1.69 \mathrm{a}$ & $1.12 \mathrm{c}$ & $2.81 \mathrm{a}$ \\
\hline Mancozeb & $0.73 \mathrm{bc}$ & $1.11 \mathrm{a}$ & $1.84 \mathrm{a}$ & $1.46 \mathrm{~b}$ & $1.33 \mathrm{~b}$ & $2,79 \mathrm{a}$ \\
\hline Control & $0.50 \mathrm{e}$ & $1.37 \mathrm{a}$ & $1.87 \mathrm{a}$ & $0.90 \mathrm{~d}$ & $1.88 \mathrm{a}$ & $2.78 \mathrm{a}$ \\
\hline
\end{tabular}

Values with the same letter in the same column are not significantly different at $\boldsymbol{P}<0.05$.

Table 4: Evaluation of the spraying of different potassium salts on total phenols content and sugars formation in onion flower stalks in open field as average of the two seasons $2017 / 2018$ and $2018 / 2019$

\begin{tabular}{|c|c|c|c|c|c|c|}
\hline \multirow{2}{*}{ Treatment } & \multicolumn{3}{|c|}{$\begin{array}{c}\text { Phenols } \\
\text { (mg/g fresh weight) }\end{array}$} & \multicolumn{3}{c|}{$\begin{array}{c}\text { Sugars } \\
(\%)\end{array}$} \\
& Free & Conj. & Total & Reduced & Non Reduced & Total \\
\hline $\mathbf{K}_{\mathbf{2}} \mathbf{H P O}_{\mathbf{4}}$ & $1.53 \mathrm{~b}$ & $0.81 \mathrm{c}$ & $2.34 \mathrm{a}$ & $1.58 \mathrm{ab}$ & $0.97 \mathrm{ab}$ & $2.55 \mathrm{a}$ \\
\hline $\mathbf{K}_{\mathbf{2}} \mathbf{C O}_{\mathbf{3}}$ & $1.18 \mathrm{e}$ & $1.11 \mathrm{a}$ & $2.29 \mathrm{a}$ & $1.38 \mathrm{ab}$ & $1.14 \mathrm{ab}$ & $2.52 \mathrm{a}$ \\
\hline K-Citrate & $1.31 \mathrm{~d}$ & $1.02 \mathrm{ab}$ & $2.33 \mathrm{a}$ & $1.35 \mathrm{ab}$ & $1.18 \mathrm{ab}$ & $2.53 \mathrm{a}$ \\
\hline K-Silicate & $1.42 \mathrm{c}$ & $0.90 \mathrm{bc}$ & $2.32 \mathrm{a}$ & $1.45 \mathrm{ab}$ & $1.09 \mathrm{ab}$ & $2.54 \mathrm{a}$ \\
\hline Mancozeb & $1.48 \mathrm{c}$ & $0.81 \mathrm{c}$ & $2.29 \mathrm{a}$ & $1.56 \mathrm{~b}$ & $0.97 \mathrm{ab}$ & $2.53 \mathrm{a}$ \\
\hline Control & $1.66 \mathrm{a}$ & $0.67 \mathrm{~d}$ & $2.33 \mathrm{a}$ & $1.71 \mathrm{a}$ & $0.83 \mathrm{~b}$ & $2.54 \mathrm{a}$ \\
\hline
\end{tabular}

Values with the same letter in the same column are not significantly different at $P<0.05$.

These positive results of free phenols and reduced sugars contents obtained from the application of K-silicate may be attributed to the beneficial effects of both $\mathrm{K}$ and silicon $(\mathrm{Si})$ for plants against environmental stresses, including biotic stress such as purple blotch (Liang et al., 2005). In addition, Si can prevent pathogen penetration into host tissues. Reduction in disease incidence in plants treated with $\mathrm{Si}$ sources under field conditions is not probably due to the fungistatic effects of $\mathrm{Si}$, but

Fayoum J. Agric. Res. \& Dev., Vol. 34, No.2 July, 2020 
EFFECT OF POTASSIUM SALTS ON ONION PURPLE

$\mathrm{Si}$ can act as physical barrier against pathogen penetration or $\mathrm{Si}$ can be used as inducer for defense response in plants (Shen et al., 2010). On the other hand, Si can stimulate accumulation of polymerized phenolic compound (Cherif and Belanger, 1992). There are numerous explanations of the Si role to suppress onion disease like: the emerging role of $\mathrm{Si}$ as a biologically active element capable of improving the natural defense system of the plant. Si-treated plants exhibited increased activity of peroxidases, chitinases, polyphenol oxidases and flavonoid phytoalexins, which play an important role in the resistance of the plant to fungal pathogens (Fawe et al., 1998). Furthermore, the higher production of glycosylated phenolics, antimicrobial products such as diterpenoid phytoalexins and a proline-rich protein in the Si-treated plants indicated that these products can have a role in the protection effects of $\mathrm{Si}$ against plant diseases (Rodrigues $\boldsymbol{e t}$ al., 2003). The bioactivity of $\mathrm{Si}$ as a regulator of plant defense mechanisms may be explained through the biochemical properties. $\mathrm{Si}$ bind with hydroxyl groups of proteins which involved in signal transduction. Also, Si may interfere with cationic co-factors of the enzymes which influencing pathogenesis-related events. Therefore, Si may interact with several key components of plant stress signaling systems leading to induced resistance (Elsharkawy et al., 2015).

The biosynthesis of the osmoregulator solutes is a physiological approach to increase disease tolerance in plants. Among them, sugars usually accumulate in response to abiotic stress (Munns and Tester, 2008). Usually, soluble carbohydrate (sugars) content was significantly increased under stress conditions. Shekari $\boldsymbol{e t}$ al. (2017) found that addition of Si increased soluble sugars content in dill plants grown under abiotic stress. Similar to phenols, increase in sugars under abiotic stress was considered as an important way for protective mechanism by means of osmotic adjustment (Munns and Tester, 2008). The beneficial effects of Si are associated with its high deposition in plant tissues, improving their strength and rigidity (Ma and Yamaji, 2006). It is also possible that Si plays an active role in resistance to plant diseases by stimulating defense mechanisms due to the increased activity of antioxidant enzymes (Balakhnina and Borkowska, 2013).

\section{CONCLUSION}

Examined potassium salts in this study gave promised safe alternative control methods for onion purple blotch in onion seed production with reference to the chemical fungicide.

Fayoum J. Agric. Res. \& Dev., Vol. 34, No.2 July, 2020 


\section{REFERENCES}

Abd El-Aal, F.S., Shafeek, M.R. Ahmed A.A., and Shaheen A.M. (2005). Response of growth and yield of onion plants to potassium fertilizer and humic acid. J. Agric. Sci. Mansoura Univ., 30(1): 315-326.

Abdel-Rahim, I.R., Abdel-Hafez, S.I.I., and Abo-Elyousr, K.A.M. (2016). Purple Blotch Disease of Onion Plant (Allium cepa L.) in Assiut, Egypt. LAP Lambert Academic Publishing, 192p.

Abou El-Nasr, M. E., and Ibrahim, E. A. (2011). Effect of different potassium fertilizers rates and foliar application with some sources of potassium on growth, yield and quality of carrot plants (Daucus carota L.). Journal of Plant Production, 2(4): 559-569.

Anonymous (2016). U.S. Food and Drug Administration (FDA) http://www.fda.gov/Food/IngredientsPackagingLabeling/GRAS/ (verified May 06, 2016).

Balakhnina, T., and Borkowska, A. (2013). Effects of silicon on plant resistance to environmental stresses: review. Int. Agrophys. 27: 225-232.

Behera, S., Santra, P., Chattopadhyay, S., Das, S., and Maity, T.K. (2014). Management of Purple blotch of onion in field through a systemic spray schedule of fungicide. J. Mycopathol. Res. 52(1): 87-91.

Bhosale, M.V., Parane, R.R., Shete, M.H., and Pawar, N.B. (2009). Efficacy of botanicals, bioagents and fungicides on management of leaf blight of onion. Ann. Plant Physiol. 23(2): 282-283.

CAPMAS (2020). Annual year book for general statistics. Egypt: Central Agency for Public Mobilization and Statistics of ARE.

Cherif, M., and Belanger, R.R. (1992). Use of potassium silicate amendments in recirculating nutrient solutions to suppress Pythium ultimum on long English cucumber. Plant Disease 79: 1008-1011.

El Rafai, Ilham,M., Asswah Susan, M.W., and Awdalla, Omaima, A. (2003). Biocontrol of some tomato diseases using some antagonistic microorganisms. Pak. J. Biol. Sci. 6(4): 399- 406.

El-Bassiouny, A.M. (2006). Effect of potassium fertilization on growth, yield and quality of onion plants. J.Appl. Sci. Res., 2(10): 780-785.

El-Beltagi, H.S., Namich, A.A.M., Helmy, S., Reman, A., and Abdel-Sattar, R. (2017). Effect of salicylic acid and potassium citrate on cotton plant under salt stress. Fresenius Environmental Bulletin, 26(1a):1091-1100.

Elsharkawy, M.M., Hase, T., Shimizu, M., and Hyakumachi, M. (2015). Suppressive effects of a polymer sodium silicate solution on powdery mildew and root rot diseases of miniature rose. Afr. J. Biotechnol. 14(42): 2917-2927.

Fawe, A., Abou-Zaid, M., Menzies, J.G., and Bélanger, R.R. (1998). Silicon mediated accumulation of flavonoid phytoalexins in cucumber. Phytopathol. 88: 396-401.

Gomez, K. A., and A. A. Gomez (1984). Statistical Procedures for Agricultural Research, $2^{\text {nd }}$ Edition. Wiley interscience publication, John Wiley \& Sons, 704pp.

Fayoum J. Agric. Res. \& Dev., Vol. 34, No.2 July, 2020 
Gupta, R.B.L., and Pathak, V.N. (1988). Survival of Alternaria porri, inducer of purple blotch of onion. Ind. Phytopathol. 41(3): 406-409.

Hwang, S.J., Park, H.M., and Jeong, B.R. (2005). Effect of potassium silicate on the growth of miniature rose 'Pinocchio' grown on rock wool and its cut flower quality. J. Japan. Soc. Hortic. Sci. 74: 242-247.

Jamar, L., Lefrancq, B., and Lateur, M. (2007). Control of apple scab (Venturia inequalis) with bicarbonate salts under controlled environment. J. Plant Dis. Protect. 114 (5): 221-227.

Khalifa, M.M.A., Fetyan, N.A.H., Abdel Magid, M.S., and El-Sheery, N.I. (2017). Effectiveness of potassium silicate in suppression white rot disease and enhancement physiological resistance of onion plants, and its role on the soil microbial community. Mid. East J. Agric. Res. 6(2): 376-394.

Lester, G.E., Jifon, J.L. \& Makus, D.J. (2010). Impact of potassium nutrition on postharvest fruit quality: Melon (Cucumis melo L) case study. Plant Soil 335, 117-131

Liang, Y.C., Sun, W.C., Si, J., and Romheld, V. (2005). Effects of foliar- and root-applied silicon on the enhancement of induced resistance to powdery mildew in Cucumis sativus. Plant Pathol. 54: 678-85.

Ma, J.F., and Yamaji, N. (2006). Silicon uptake and accumulation in higher plants. Trends Plant Sci. 11: 392-397.

Marschner H. (1995). Mineral nutrition of higher plants. second edition. 889pp. London: Academic Press Annals of Botany, 78(4): 527-528

Marschner, P. (2012). Marschner's Mineral Nutrition of Higher Plants, $3^{\text {rd }}$ ed., Academic Press: London, UK.

Mengel, K. 2007. "Potassium". In: Barker, A. V. and Pilbeam, D. J. (ed). Handbook of Plant Nutrition, pp 91-120. Boca Ratan, FL, USA: Taylor \& Francis.

Munns, R., and Tester, M. (2008). Mechanisms of salinity tolerance. Ann. Rev. Plant Biol. 59: 651-681.

Niua, J., Zhang W., Ruc S., Chen X., Xiao K., Zhang X., Assaraf M., Imas, P., Magen H., Zhang, F. (2013). Effects of potassium fertilization on winter wheat under different production practices in the North China Plain. Field Crops Research, 140: 69-76.

Palmer, C.L., Horst, R.K., and Langhans, R.W. (1997). Use of bicarbonates to inhibit in vitro colony growth of Botrytis cinerea. Plant Dis. 81: 14321438.

Perrenoud, S. (1990). Potassium and Plant Health. IPI Research. Topics No. 3, second ed. International Potash Institute, Bern Switzerland, 365 p.

Quadri, S.M.H, Srivastava, J.K., Bhode, S.R., Pandey, U.B., and Bhagchandani P.M. (1982). Fungicidal bioassays against some important pathogens of onion. Pesticides., $16: 11-16$.

Ravichandran, S., Kamanna, B.C., Jayalakshmi, K., Benagi, V.I. and K.B. Yadahalli (2017). Severity of Purple Blotch of Onion Caused by Alternaria porii in Northern Karnataka, India. International Journal of Current Microbiology and Applied Sciences, 6(12): 3634-3638.

Fayoum J. Agric. Res. \& Dev., Vol. 34, No.2 July, 2020 
Hanan S. Sofy et al.,

Reezi, S., Babalar, M., and Kalantari, S. (2009). Silicon alleviates salt stress. Decrease malondialdehyde content and affects petal color of salt stressed cut rose (Rosaxhybridal.), Hot Lady. Afr. J. Biotechnol. 8: 1502-1508.

Rodrigues, F.A., Benhamou, N., Datnoff, J.B., Jones, B., and Bélanger, R.R. (2003). Ultrastructural and cytochemical aspects of silicon-mediated rice blast resistance. Phytopathol. 93: 535-546.

Saud, S., Chun, J., Razaq, M., Luqman, M., Fahad, S., Abdullah, M., and Sadiq, A. (2013). Effect of potash levels and row spacing on onion yield. Journal of Biology, Agriculture and Healthcare, Vol.3, No.16: 118-127.

Shafeek, M.R., Hassan, N.M.K., Singer, S.M., and El-Greadly, N.H.M (2013). Effect of potassium fertilizer and foliar spraying with Etherel on plant development, Yield and bulb Quality of onion plants (Allium cepa L.). J of Appl. Sci. Res., 9 (2):1140-1146.

Sharma, S.R. (1986). Effect of fungicidal sprays on purple blotch and bulb yield of onion. Indian Phytopath., 39:78-82.

Shekari, F., Abbasi, A., and Mustafavi, S.H. (2017). Effect of silicon and selenium on enzymatic changes and productivity of dill in saline condition. J. Saudi Soc. Agric. Sci. 16(4): 367-374.

Shen, G.H., Xue, Q.H., Tang, M., Chen, Q., Wang, L.N., Duan, C.M., Xue, L., and Zhoo, J. (2010). Inhibitory effects of potassium silicate of five soilborne phytopathogenic fungi in vitro. J. Plant Dis. Protect. 117(4): 180184.

Singh, N., Kaur, L., and Singh, J. (2004). Relationships between various physicochemical, thermal and rheological properties of starches separated from different potato cultivars. Journal of the Science of Food and Agriculture, 84(7):714-720.

Strömberg, A. and Brishammar, S. (1991). Induction of systemic resistance in potato (Solanum tuberosum L.) plants to late blight by local treatment with Phytophthora infestans (Mont.) de Bary, Phytophthora cryptogea Pethyb. \& laff. or dipotassium phosphate. Potato Research. 34. 219-225.

Wheeler, B.E.J. (1969). An introduction to plant diseases. John Willey and Sons Ltd. London, 301.

Youssef, K., Ligorio, A., Sanzani, S.M., Nigro, F., and Ippolito, A. (2012). Control of storage diseases of citrus by pre and postharvest application of salts. Postharvest Biol. Technol. 72: 57-63.

Yurina, T.P., V.A. Karavaev and M.K. Solntsev, (1993). Characteristics of metabolism in two cucumber cultivars with different resistance to powdery mildew. Russian Plant Physiol., 40: 197-202.

Fayoum J. Agric. Res. \& Dev., Vol. 34, No.2 July, 2020 
تأثير بعض أملاح البوتاسيوم على إصابة نباتات البصل لانتاج البذور بمرض اللطخة الارجوانية وعلى بعض

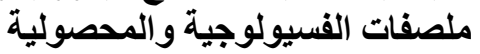

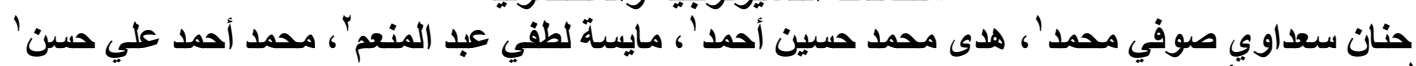

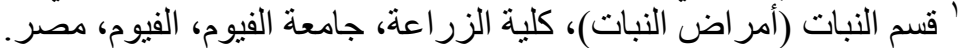

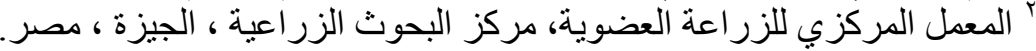

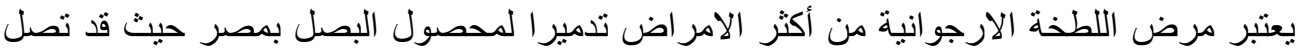

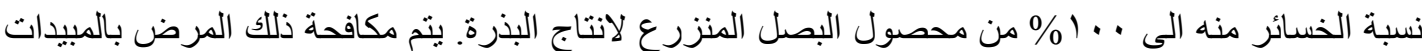

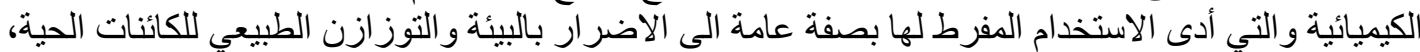

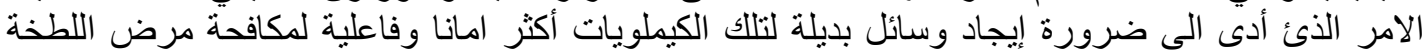

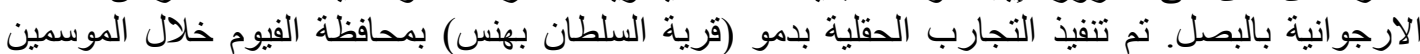

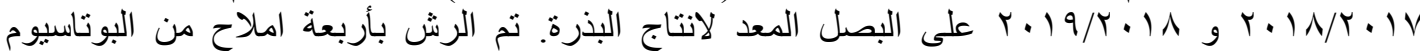

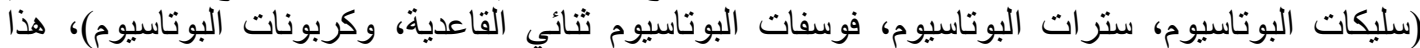

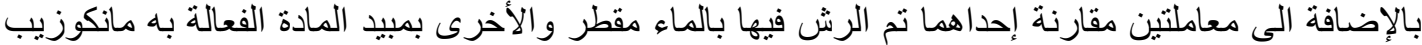

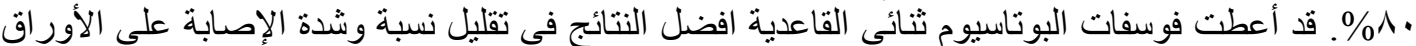

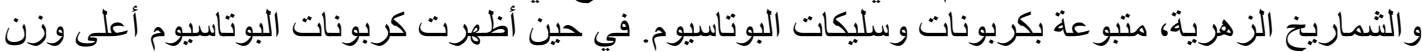

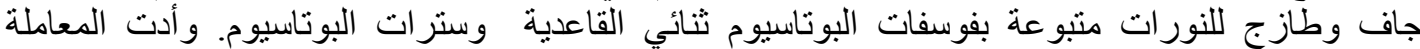

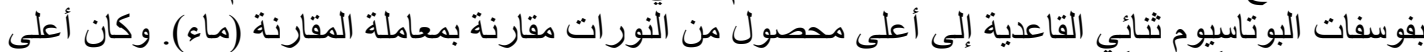

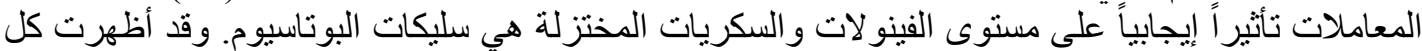

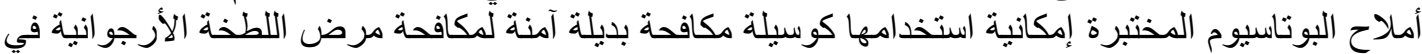

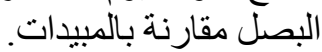

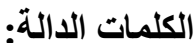
بصل لانتاج البذرة، البوتاسيوم، سليكات، سترات، فوسفات، كربونات، اللطخة الارجو انية. 